\title{
Inhibition of 3-hydroxy-3-methyl-glutaryl- coenzyme A reductase enzyme by dipeptides identified in dry-cured ham
}

\author{
Alejandro Heres, Leticia Mora* (i) and Fidel Toldrá
}

\begin{abstract}
High cholesterolemia is a key risk factor for the development of cardiovascular diseases, which are the main cause of mortality in developed countries. Most therapies are focused on the modulation of its biosynthesis through 3hydroxy-3-methylglutaryl-coenzyme A reductase (HMG-CoAR) inhibitors. In this sense, food-derived bioactive peptides might act as promising health alternatives through their ability to interact with crucial enzymes involved in metabolic pathways, avoiding the adverse effects of synthetic drugs. Dry-cured ham has been widely described as an important source of naturally-generated bioactive peptides exerting ACEl-inhibitory activity, antioxidant activity, and anti-inflammatory activity between others. Based on these findings, the aim of this work was to assess, for the first time, the in vitro inhibitory activity of HMG-CoAR exerted by dipeptides generated during the manufacturing of dry-cured ham, previously described with relevant roles on other bioactivities.

The in vitro inhibitory activity of the dipeptides was assessed by measuring the substrate consumption rate of the 3-hydroxy-3-methylglutaryl CoA reductase in their presence, with the following pertinent calculations.

Further research was carried out to estimate the possible interactions of the most bioactive dipeptides with the enzyme by performing in silico analysis consisting of molecular docking approaches.

Main findings showed DA, DD, EE, ES, and LL dipeptides as main HMG-CoAR inhibitors. Additionally, computational analysis indicated statin-like interactions of the dipeptides with HMG-CoAR.

This study reveals, for the first time, the hypocholesterolemic potential of dry-cured ham-derived dipeptides and, at the same time, converges in the same vein as many reports that experimentally argue the cardiovascular benefits of dry-cured ham consumption due to its bioactive peptide content.
\end{abstract}

Keywords: Dipeptides, Dry-cured ham, Bioactivity, HMG-CoA reductase

\section{Introduction}

Hypercholesterolemia leads to a pathogenic accumulation of low-density-lipoproteins (LDL) in blood vessels and the formation of atherosclerotic plaques, highly associated with the development of cardiovascular diseases (CVDs), which are one of the main global causes of death (Gallego et al. 2019a; Nagaoka 2019; Zalesin et al. 2011). Cholesterol synthesis consists of various steps and it is regulated at several points. The

\footnotetext{
* Correspondence: lemoso@iata.csic.es

Instituto de Agroquímica y Tecnología de Alimentos (CSIC), Avenue Agustín Escardino 7, 46980 Valencia, Paterna, Spain
}

most relevant step is the reduction of 3-hydroxy-3methylglutaryl-CoA (HMG-CoA) to mevalonate, by the enzyme HMG-CoA reductase (HMG-CoAR), using two NADPH as cofactors. This is the ratelimiting step of the overall synthesis of cholesterol and it constitutes a target on which many hypolipemic therapies are based on (Gesto et al. 2020). Statins are competitive inhibitors of HMG-CoAR but unfortunately, can cause neuromuscular disorders and rhabdomyolysis as secondary effects and are contraindicated for patients with previous liver diseases

(c) The Author(s). 2021, corrected publication 2021. Open Access This article is licensed under a Creative Commons Attribution 4.0 International License, which permits use, sharing, adaptation, distribution and reproduction in any medium or format, as long as you give appropriate credit to the original author(s) and the source, provide a link to the Creative Commons licence, and indicate if changes were made. The images or other third party material in this article are included in the article's Creative Commons licence, unless indicated otherwise in a credit line to the material. If material is not included in the article's Creative Commons licence and your intended use is not permitted by statutory regulation or exceeds the permitted use, you will need to obtain permission directly from the copyright holder. To view a copy of this licence, visit http://creativecommons.org/ licenses/by/4.0/. 
(Crisan \& Patil 2020; Hashiguchi et al. 2018; OchsBalcom et al. 2019; Suganya et al. 2017).

By controlling enzymatic pathways, the aim of prevention and treatment of human diseases has led to discover food compounds which may serve as agents against several disorders. In this sense, food-derived peptides can present low toxicity and accumulation in tissue (La Manna et al. 2018). Therefore, dietary bioactive peptides could mean a simple way of therapy avoiding treatments with side effects (Yao et al. 2018).

Dry-cured hams are protein-rich foods, and due to the proteolytic process associated with the dry-curing stage, they may constitute a highly potential source of bioactive peptides (Kęska \& Stadnik 2016, 2017). As a result of endogenous proteolytic enzyme activities, the length of the polypeptides is progressively reduced, leading to the generation of short peptides (Toldrá et al. 2020) which are responsible of the final characteristics of the product, but also of its functional properties (Gallego et al., 2015, Gallego et al. 2019b, Mora et al. 2019). Regarding the biological activity, in vitro angiotensin I-converting enzyme (ACEI), dipeptidyl peptidase-IV (DPP-IV), $\alpha-$ amylase and $\alpha$-glucosidase inhibitory activities, antiinflammatory, antioxidant, and antilisterial activities have been reported (Castellano et al. 2016; Gallego et al. 2014; Gallego et al. 2016; Gallego et al. 2019a; Mora et al. 2020). Also several in vivo and clinical studies have been conducted, demonstrating antihypertensive and anti-inflammatory effects of dry-cured ham derived peptides (Escudero et al. 2012; Escudero et al. 2013; Martínez-Sánchez et al. 2017; Montoro-García et al. 2017).

The main limiting fact for peptides to exert beneficial effects is their susceptibility to a partial or total loss of activity as a result of food matrix interactions and further hydrolysis by digestive enzymes and intestinal microbiota. Finally, peptides must reach their target sites in an active form in significant quantity (Gallego et al. 2016; Toldrá et al. 2020). In this sense, dipeptides are of great therapeutic interest because they can be absorbed more efficiently in the intestinal tract (Bouglé \& Bouhallab 2017; Guha \& Majumder 2019) and arrive intact through the blood stream to the target sites of the organs where they could exert their functionalities.

According to this, the aim of this work was to test the in vitro HMG-CoAR inhibitory activity of different dipeptides previously reported to be generated during proteolysis in Spanish dry-cured ham. These dipetides were selected for their potential to act as multifunctional peptides due to they have already been confirmed in previous experiments to exert other biological activities. Molecular docking computational analysis was carried out to predict statin-like interactions of the dipeptides with HMG-CoAR.

\section{Results and discussion}

The assayed dipeptides were chosen for being previously reported to be present in dry-cured ham by tandem mass spectrometry and in silico approaches (Kęska \& Stadnik 2017; Mora et al. 2019; Zhou et al. 2020). The dipeptides were selected for their potential to act as multifunctional peptides due to they have already been confirmed in previous experiments to be able to exert other biological activities. Table 1 summarizes the protein of origin and main physicochemical characteristics attributed to the dipeptides of this study, whereas Table 2 includes other biological activities previously defined for these peptide sequences. In this sense, the dipeptide EE from $\beta$-conglycinin has been shown to reduce concentrations of endotelin-1 in human aortic endothelial cells, displaying a regulatory vasoactive substance release activity (Ringseis et al. 2005); while the dipeptide ES has also been previously described as an in vitro dipeptidyl peptidase IV inhibitor (Lan et al. 2015). Otherwise, the dipeptide DA has been proved as inhibitor of both ACEI and DPP-III enzymes (Cushman et al. 1981; Dhanda et al. 2007). On the other hand, AA has been documented as in vitro ACEI and DPP-IV inhibitor (Gallego et al. 2014; Sentandreu \& Toldrá 2007); AL and VH have been registered as in vitro DPP-IV inhibitors and to exert anti-inflammatory effects on lipopolysaccharideinduced RAW 264.7 macrophages (Lan et al. 2015; Nongonierma et al. 2014; Zhao et al. 2016). AQ supplementation patients with severe burns can reduce the infection rate, wound healing time, intestinal permeability and serum endotoxin concentration at the same time that plasma Q levels are increased (Zhou et al. 2004). Moreover, this dipeptide, and also QQ, decreases the release of pro-inflammatory cytokines by polymorphonuclear leukocytes, while expression of the antiinflammatory IL-10 is enhanced (Fürst et al. 2004). On other hand, LL was demonstrated to act as an in vitro DPP-IV inhibitor and as glucose uptake stimulating compound in L6 myotubes cell cultures (Bella et al. 1982; Morifuji et al. 2009), but also was predicted to have a role as anti-inflammatory via in silico analysis (Gupta et al. 2017). Finally, QQ was identified as in vitro DPP-IV inhibitor (Lan et al. 2015).

Regarding the variety of activities, it is important to consider that due to the link between metabolic pathways, bioactive peptides might act on different targets to regulate biological functions.

A further point is that the majority of the dipeptides of this work have also been correlated with different tastes that could influence on the typical organoleptic properties of dry-cured hams (Arai et al. 1972; Asao et al. 1987; Kim et al. 2015; Kuramitsu et al. 1996; Maehashi et al. 1999; Noguchi et al. 1975; Ohyama et al. 1988; Shim et al. 2015; Tamura et al. 1989; van den 
Table 1 Parental proteins and main physicochemical characteristics attributed to the dipeptides of this study

\begin{tabular}{|c|c|c|c|c|c|}
\hline Dipeptide $^{a}$ & Dry-cured ham parental protein & Net charge at $\mathrm{pH} 7(\text { value }(\mathrm{pl}))^{\mathrm{b}}$ & Hydrophobicity $^{c}$ & $\begin{array}{l}\text { Steric } \\
\text { hindrance }^{c}\end{array}$ & 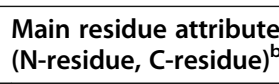 \\
\hline$\overline{A A}$ & $\begin{array}{l}\text { Myosin Light Chain } 1 \\
\text { (Mora et al. 2019) }\end{array}$ & $0(3.69)$ & 0.25 & 0.52 & aliphatic, aliphatic \\
\hline $\mathrm{AL}$ & $\begin{array}{l}\text { Myosin Light Chain } 1 \\
\text { LIM domain-binding } 3 \\
\text { (Mora et al. 2019) }\end{array}$ & $0(3.7)$ & 0.39 & 0.53 & aliphatic, aliphatic \\
\hline $\mathrm{AQ}$ & $\begin{array}{l}\text { LIM domain-binding } 3 \\
\text { (Mora et al. 2019) }\end{array}$ & $0(3.77)$ & -0.22 & 0.60 & aliphatic, polar \\
\hline AW & $\begin{array}{l}\text { Nebulin (Kęska \& Stadnik 2016) } \\
\text { (in silico) }\end{array}$ & $0(3.66)$ & 0.31 & 0.51 & aliphatic, aromatic \\
\hline DA & $\begin{array}{l}\text { Myosin light chain isoforms } \\
\text { (Zhou et al. 2020) }\end{array}$ & $-1(0.69)$ & -0.23 & 0.64 & acidic, aliphatic \\
\hline $\mathrm{DD}$ & $\begin{array}{l}\text { Sarcoplasmic \& myofibrillar proteins } \\
\text { (Kęska \& Stadnik 2017) } \\
\text { (in silico) }\end{array}$ & $-2(0.73)$ & -0.72 & 0.76 & acidic, acidic \\
\hline DG & $\begin{array}{l}\text { Sarcoplasmic \& myofibrillar proteins } \\
\text { (Kęska \& Stadnik 2017) } \\
\text { (in silico) }\end{array}$ & $-1(0.68)$ & -0.28 & 0.72 & acidic, aliphatic \\
\hline $\mathrm{EE}$ & $\begin{array}{l}\text { Titin (Gallego et al. 2015) } \\
\text { Myosin light chain isoforms } \\
\text { (Zhou et al. 2020) }\end{array}$ & $-2(0.85)$ & -0.62 & 0.68 & acidic, acidic \\
\hline ES & $\begin{array}{l}\text { Sarcoplasmic \& myofibrillar } \\
\text { proteins } \\
\text { (Kęska \& Stadnik 2017) } \\
\text { (in silico) }\end{array}$ & $-1(1.01)$ & -0.44 & 0.60 & acidic, polar \\
\hline EV & $\begin{array}{l}\text { Sarcoplasmic \& myofibrillar proteins } \\
\text { (Kęska \& Stadnik 2017) } \\
\text { (in silico) }\end{array}$ & $-1(0.94)$ & -0.04 & 0.69 & acidic, aliphatic \\
\hline GA & & $0(3.63)$ & 0.21 & 0.60 & aliphatic, aliphatic \\
\hline $\mathrm{LE}$ & $\begin{array}{l}\text { Sarcoplasmic \& myofibrillar } \\
\text { proteins } \\
\text { (Kęska \& Stadnik 2017) } \\
\text { (in silico) }\end{array}$ & $-1(1)$ & -0.04 & 0.60 & aliphatic, acidic \\
\hline $\mathrm{LL}$ & $\begin{array}{l}\text { Lactate dehydrogenase } \\
\text { (Mora et al. 2019) }\end{array}$ & $0(3.63)$ & 0.53 & 0.53 & aliphatic, aliphatic \\
\hline PA & $\begin{array}{l}\text { LIM domain-binding } 3 \\
\text { Myosin Light Chain } 1 \\
\text { Titin (Mora et al. 2019) }\end{array}$ & $0(4.07)$ & 0.09 & 0.44 & aliphatic, aliphatic \\
\hline QQ & & $0(3.41)$ & -0.69 & 0.68 & polar,polar \\
\hline VG & $\begin{array}{l}\text { Sarcoplasmic \& myofibrillar } \\
\text { proteins } \\
\text { (Kęska \& Stadnik 2017) } \\
\text { (in silico) }\end{array}$ & $0(3.59)$ & 0.35 & 0.69 & aliphatic, aliphatic \\
\hline $\mathrm{VH}$ & Troponin T (Mora et al. 2016) & $0.1(7.78)$ & 0.07 & 0.35 & aliphatic, basic \\
\hline
\end{tabular}

Peptide sequences are given as amino acids one-letter code. ${ }^{\mathrm{b}} \mathrm{Net}$ charges at $\mathrm{pH}$, pl values, and main residue attribute obtained from PepCalc (https://pepcalc. com/) (access Nov 2020). ' $H y$ drophobicity and steric hindrance values obtained form ToxinPred (https://webs.iiitd.edu.in/raghava/toxinpred/multi_submitfreq_S. php?ran=22308) (access Nov 2020)

Oord \& van Wassenaar 1997). Hence, their relevance can take on a new sense in terms of their multifunctionality as bioactive and taste-active compounds.

HMG-CoA inhibitory bioactivity of the selected dipeptides The anti-hypercholesterolemic activity of the dipeptides was assayed measuring the inhibition percentages of HMG-CoAR.
As it can be seen in Table 3, the dipeptides DA, EE, ES, and LL, tested at $1 \mathrm{Mm}$, showed the highest inhibition percentages (more than $40 \%$ ), followed by the dipeptides DD and VH. The dipeptides AW, DG, EV, GA, LE, PA and VG showed null inhibition. Finally, the rest of the dipeptides showed approximately above $10 \%$ of inhibition, except for QQ. Pravastatin, used as positive control, reached inhibition values slightly higher than 
Table 2 Other bioactivities attributed to the dipeptides of this study

\begin{tabular}{|c|c|c|c|}
\hline Dipeptide $^{a}$ & Bioactivity & Biological system & Reference \\
\hline \multirow[t]{2}{*}{ AA } & in vitro $A C E l$ inhibitor & cardiovascular & Gallego et al., 2014 \\
\hline & in vitro DPP-IV inhibitor & endocrine & Sentandreu \& Toldrá, 2007 \\
\hline \multirow[t]{2}{*}{ AL } & in vitro DPP-IV inhibitor & endocrine & Nongonierma et al., 2014 \\
\hline & inhibition of NO production in RAW 264.7 & immune & Zhao et al., 2016 \\
\hline \multirow[t]{2}{*}{$\mathrm{AQ}$} & intestinal permeability reduction and wound-healing properties & digestive & Zhou et al., 2004 \\
\hline & inhibition of pro-inflammatory cytokines by polymorphonuclear leukocytes & immune & Fürst et al., 2004 \\
\hline \multirow[t]{4}{*}{ AW } & in vitro antioxidant & cardiovascular & Liu et al., 2015 \\
\hline & in vitro $A C E l$ inhibitor & endocrine & Loponen, 2008 \\
\hline & in vitro DPP-IV inhibitor & & Nongonierma et al., 2014 \\
\hline & in silico renin inhibitor & & Udenigwe, Li, \& Aluko, 2012 \\
\hline \multirow[t]{2}{*}{ DA } & in vitro $A C E l$ inhibitor & cardiovascular & Cushman et al., 1981 \\
\hline & in vitro DPP-III inhibitor & endocrine & Dhanda et al., 2007 \\
\hline DD & (absent) & & \\
\hline DG & in vitro $A C E l$ inhibitor & cardiovascular & Meisel et al., 2006 \\
\hline $\mathrm{EE}$ & stimulating vasoactive substance release & cardiovascular & Ringseis et al., 2005 \\
\hline ES & in vitro DPP-IV inhibitor & endocrine & Lan et al., 2015 \\
\hline \multirow[t]{2}{*}{ EV } & in vitro $A C E l$ inhibitor & cardiovascular & van Platerink et al., 2008 \\
\hline & in vitro DPP-IV inhibitor & endocrine & Lan et al., 2015 \\
\hline \multirow[t]{2}{*}{ GA } & ACEl inhibitor & cardiovascular & Cheung et al., 1980 \\
\hline & in vitro DPP-IV inhibitor & endocrine & Hikida et al., 2013 \\
\hline LE & (absent) & & \\
\hline \multirow[t]{3}{*}{$\mathrm{LL}$} & in vitro DPP-IV inhibitor & endocrine & Bella et al., 1982 \\
\hline & glucose uptake stimulating compound & immune & Morifuji et al., 2009 \\
\hline & in silico anti-inflammatory compound & & Gupta et al., 2017 \\
\hline PA & in vitro DPP-IV inhibitor & endocrine & Bella et al., 1982 \\
\hline \multirow[t]{2}{*}{ QQ } & in vitro DPP-IV inhibitor & endocrine & Lan et al., 2015 \\
\hline & inhibition of pro-inflammatory cytokines by polymorphonuclear leukocytes & immune & Fürst et al., 2004 \\
\hline \multirow[t]{2}{*}{ VG } & in vitro $A C E l$ inhibitor & cardiovascular & Cheung et al., 1980 \\
\hline & in vitro DPP-IV inhibitor & endocrine & Lan et al., 2015 \\
\hline \multirow[t]{2}{*}{$\mathrm{VH}$} & in vitro DPP-IV inhibitor & endocrine & Lan et al., 2015 \\
\hline & inhibition of NO production in RAW 264.7 & immune & Zhao et al., 2016 \\
\hline
\end{tabular}

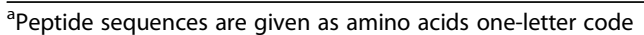

$70 \%$ with a concentration of $2.5 \mu \mathrm{M}$ (Fig. 1). Those peptides with the highest inhibitory activity were tested at different concentrations, as it is shown in Fig. 2. Additionally, to evaluate the possibility of an in vitro synergistic effect, two sets of dipeptides at $1 \mathrm{mM}$ were assayed. Set 1 was formed by the most active dipeptides DA, DD, EE, ES, LL, and VH, while Set 2 consisted of $\mathrm{AA}, \mathrm{AL}, \mathrm{AQ}$, and $\mathrm{QQ}$. However, no significative increment in the inhibition activity was observed (Table 3), thus, ruling out synergistic effects in the in vitro test. According to the inhibition activity of the Set 1 , it might mean that dipeptides could act by a non-synergistic inhibition mechanism which relies on the global concentration of peptides with specific structural properties.
Main results suggest that the acidic character of $\mathrm{D}$ and $\mathrm{E}$ of dipeptides DA, DD, EE, and ES could help them to bind the enzyme and reduce its activity. This fact may permit short peptides to access the catalytic site of the enzyme and simulate the HMG-like moiety of statins, which is bound in the narrow pocket of the active site (Pak et al. 2006). AA, AQ, AL, QQ and VH revealed the forming residues would have a less relevant role in inhibition of this enzyme. In general, the most active dipeptides meet the condition of having a pI under, or similar, to 1.0. Besides, they also present lower hydrophobicity values except DA. In addition, the steric hindrance seems to play a moderate influence, due to the fact that DA, DD, EE and ES are of those with the 
Table 3 HMG-CoA reductase (HMG-COAR) inhibitory activity of the assayed dipeptides at $1 \mathrm{mM}(n>3)$

\begin{tabular}{|c|c|c|c|}
\hline \multicolumn{2}{|c|}{ Dipeptide } & \multirow{2}{*}{$\begin{array}{l}\% \text { Inhibition } \\
13.80^{\mathrm{e}}\end{array}$} & \multirow{2}{*}{$\frac{S D}{5.84}$} \\
\hline$\overline{\mathrm{AA}}$ & Ala-Ala & & \\
\hline $\mathrm{AL}$ & Ala-Leu & $13.02^{e}$ & 1.82 \\
\hline $\mathrm{AQ}$ & Ala-Gln & $11.34^{\mathrm{e}, f}$ & 3.55 \\
\hline AW & Ala-Trp & n. s. $^{9}$ & n.s. \\
\hline DA & Asp-Ala & $49.57^{a}$ & 5.49 \\
\hline DD & Asp-Asp & $33.04^{c, d}$ & 6.23 \\
\hline DG & Asp-Gly & n. s. ${ }^{9}$ & n.s. \\
\hline EE & Glu-Glu & $47.26^{a, b}$ & 7.40 \\
\hline ES & Glu-Ser & $45.49^{a, b}$ & 6.28 \\
\hline EV & Glu-Val & n. s. ${ }^{9}$ & n.s. \\
\hline GA & Gly-Ala & n. s. ${ }^{9}$ & n.s. \\
\hline LE & Leu-Glu & n. s. ${ }^{9}$ & n.s. \\
\hline $\mathrm{LL}$ & Leu-Leu & $48.32^{\mathrm{a}}$ & 5.87 \\
\hline PA & Pro-Ala & n. s. ${ }^{9}$ & n.s. \\
\hline QQ & Gln-Gln & $4.71^{\mathrm{f}, \mathrm{g}}$ & 1.39 \\
\hline VG & Val-Gly & n. s. ${ }^{g}$ & n.s. \\
\hline $\mathrm{VH}$ & Val-His & $28.63^{d}$ & 8.48 \\
\hline SET 1 & & $39.73^{b, c}$ & 1.91 \\
\hline SET 2 & & n. s. ${ }^{9}$ & n.s. \\
\hline
\end{tabular}

Set 1 refers to the peptide group $\mathrm{DA}, \mathrm{DD}, \mathrm{EE}, \mathrm{ES}, \mathrm{LL}$, and $\mathrm{VH}$ at $1 \mathrm{mM}$; Set 2 refers to the peptide group $A A, A L, A Q$, and $Q Q$ at $1 \mathrm{mM}$. Letters designate significant differences among the values at $P<0.05$. n. s. indicates non-significant inhibition

highest values. Globally, it can be said that aliphatic residues do not attribute any remarkable inhibition capacity (Table 1).

In this sense, $\mathrm{T}$ - and E-residues have been proposed to act as mimics of an HMG moiety for the HMGCoA interacting site and facilitate the formation of additional $\mathrm{H}$ bonds that intensify the attachment with the binding site and the stabilization of the conformation (Pak et al. 2005a; Pak et al. 2007). In fact, the E-residue located at the $\mathrm{C}$-terminus has been pointed out as an essential character for the recognition of the HMG binding site (Pak et al. 2012). In addition, it has been suggested that a positively charged residue at $\mathrm{C}$-terminus is unfit within the positively charged residues of the HMG-CoA subpocket, whereas a Dresidue in $\mathrm{C}$-terminal position, makes the interaction more feasible (Lammi et al. 2016a). On the other hand, a number of studies have reported that the hypocholesterolemic effect correlates to increased hydrophobicity, but in contrast, a research carried out on tetrapeptides obtained an inverse correlation between hydrophobicity and the inhibitory activity (Pak et al. 2006). Here, polar acidic E- and D-residues exhibited a more relevant role over the rest of the residues, as all peptides containing $\mathrm{E}$ and $\mathrm{D}$ amino acids exerted inhibition,. Also, polar weak basic Q-residue seemed to attribute a fairly capacity of inhibition.

Additionally, certain structure-functional analyses focused on tetrapeptides showed that an E-residue in the C-terminus and L-, I- or Y-residues at N-terminal position, benefit the inhibitory bioactivity (Pak et al., 2005c), which could partially explain the inhibition observed on the dipeptide LL, although LE dipeptide did not showed a significant inhibitory activity. A- and V-residues could have a steric effect due to their aliphatic side chains at positions 2 and 3 in tetrapeptides, and that might be the reason of the inhibitory effect observed in $\mathrm{AA}, \mathrm{AL}, \mathrm{AQ}$ and $\mathrm{VH}$ dipeptides. A P-residue is also considered to mimic the nicotinamide moiety of NADPH, conferring a "turn" structure which promotes docking by imitating statins (Coelho et al. 2018; Pak et al. 2010). The presence of cationic amino acids such as $\mathrm{H}$-residues has been correlated with a hypolipidemic effect, but mainly due to their ability to interact with the carboxylic groups of bile acids (Yao et al. 2018). Moreover, the analysis of the superposition of statins and peptide molecules showed a similar location of the iso-butyl (compactin and simvastatin) and the benzene ring of the 4fluorophenyl radical of statins (fluvastatin, cerivastatin, atorvastatin, and rosuvastatin) with the side-chains of Iand Y-residues, respectively, and an aryl radical in the $\mathrm{N}$-terminal increases the inhibitory activity of tetrapeptides (Pak et al. 2006). Basing on this, perhaps the imidazole ring system of $\mathrm{H}$-residue, which has an aromatic character due to the presence of a planar ring containing $6 \pi$-electrons, could contribute to an inhibitory effect although it is located at the C-terminus in the dipeptide $\mathrm{VH}$. However, the residue position in a dipeptide may be not so essential as their small size might provide them with versatility in terms of spatial distribution.

Several reports have denoted the potential HMGCoAR inhibitory effect of some peptides. Peptide extracts with molecular mass lower than $3 \mathrm{kDa}$ from different sources, such as chia protein extracts and cowpea, reduced the HMG-CoAR enzymatic reaction velocity (Coelho et al. 2018; Marques et al. 2015). Additionally, the hydrolysis product of snakehead fish skin collagen has also been reported as anticholesterolemic agent (Virginia et al. 2016). In other hand, phage-display techniques also revealed the tetrapeptide PMAS is a strong inhibitor (Lin et al. 2015). Particularly, it has been identified several short food-derived HMG-CoAR inhibitory peptides (Nagaoka, 2019) and have served to design stronger structural derivatives. This is the case of SFGYVAE, IAVP and GFPTGG, which are inspired from soy glycinin-derived peptides IAVPGEVA, IAVPTGVA and LPYP. As a result of this research, the YVAE sequence was characterized as a recognized motif (Pak et al., 2005b; Pak et al. 2007, 2008, 2012). It has been 


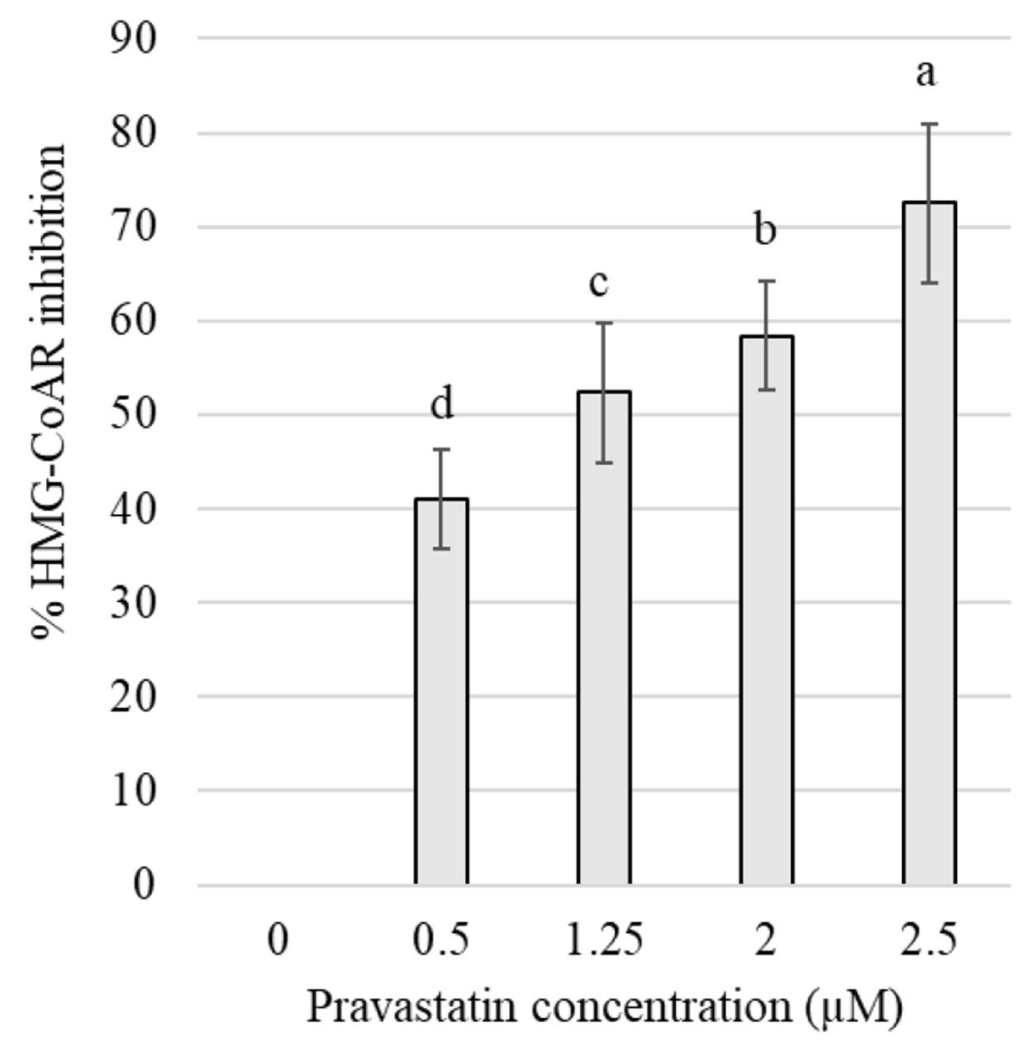

Fig. 1 Inhibition percentages of pravastatin at different concentrations $(\mu \mathrm{M})(n>3)$. Letters indicate significant differences among the values at $P<0.05$

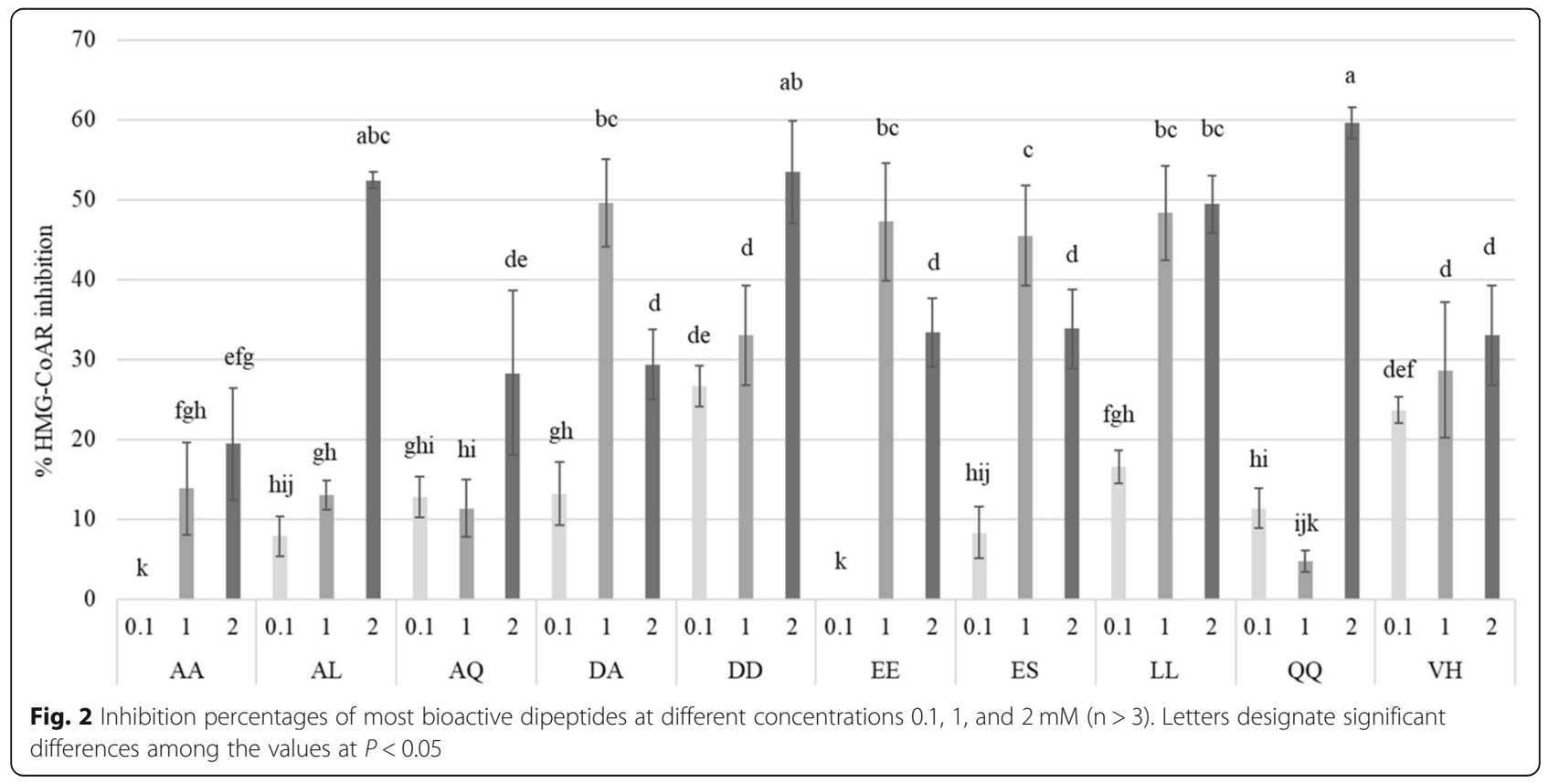


demonstrated that lupin peptides, soy $\beta$-conglycininderived peptides YVVNPDNDEN and YVVNPDNNEN; and LILPKHSDAD and LTFPGSAED, derived from lupin $\beta$-conglutin, are able to regulate the cholesterol metabolism at HepG2 cell line (Lammi et al. 2014, 2015). Peptides GGV, IVG, and VGVL generated by in vitro hydrolysis of Amaranthus cruentus protein; and QDF, derived from cowpea $\beta$-vignin protein have been also reported as hypocholesterolemic peptides (Soares et al. 2015). More recently, a peptide from an Indonesian fermented fish and different peptide fractions from Japanese traditional fermented fishes have been described to inhibit HMG-CoAR enzyme (Rinto et al. 2017).

According to our knowledge, no evidence has been published to date about dry-cured ham hypocholesterolemic properties due to the presence of HMGCoAR inhibitory dipeptides. It is known that drycured ham is a traditional Spanish food with numerous reports correlating the generation of bioactive peptides with counteracting effects related to hypertension, thrombotic issues, and inflammation processes, despite its salt content. A research on postmenopausal women, reviewed no prejudicial effects on the lipid profile after the consumption of acornfed Iberian ham rich in oleic acid. Total cholesterol, triglycerides (TG), LDL-cholesterol, and fibrinogen levels dropped significantly after the consumption of a diet rich in oleic acid, a part of which was from acorn-fed Iberian ham, while they were sustained after another diet whose oleic acid came from olive oil. Also, no changes were detected on high density lipoprotein (HDL)-cholesterol, Apo A and B and lipoprotein (Rebollo et al. 1998). In agreement, a prospective and dynamic epidemiologic cohort, recorded that after 6 years of consumption of drycured ham by university graduates, no association was found between higher levels of consumption of dry-cured ham and the incidence of cardiovascular disease, hypertension and weight gain (Ruiz-Canela López et al. 2009). More recently, a two-arm, crossover, randomised controlled trial in healthy patients with hypertension, showed that consumption of drycured ham attenuates platelet and monocyte activation and it diminishes plasmatic P-selectin, monocyte chemoattractant protein-1 and interleukin 6 levels (Martínez-Sánchez et al. 2017). In accordance with these outcomes, another two-arm, cross-over, randomised controlled trial revealed regular dry-cured ham consumption had a lipid-lowering effect, with decreases in total cholesterol, LDL and TG levels, and in glycaemia. What is more, no significant changes were detected in HDL, TG/HDL-cholesterol, and LDL/HDL-cholesterol ratios after any treatment nor in blood pressure. Additionally, the study also identified several bioactive peptides in the interventional product with previously demonstrated antihypertensive bioactivity. Those observations suggested an intake-dependent improvement in the thrombogenic and inflammatory status and it might be due to the bioactivity of the peptides generated in drycured ham (Montoro-García et al. 2017).

Nevertheless, this is the first time that an inhibitory activity on HMG-CoAR is related to dipeptides generated in dry-cured ham.

\section{Docking results}

Those dipeptides showing the highest in vitro inhibitory activity were studied through molecular docking analyses to understand their possible mechanism of inhibition. As it is showed in Table 4 and Fig. 3, the computational process between HMG-CoAR and the studied dipeptides permits to estimate interacting residues, binding type, and binding energy of interactions.

Data suggested that pravastatin makes interactions with key enzyme residues as Ser684, Asp690, Lys691, Lys692 from one chain and Glu559, Lys735, His752, Asn755 and Leu853 from the other chain. These predictions indicated that pravastatin establishes typical statin HMG-moieties interactions, some of them identical to those observed between protein and substrate HMG$\mathrm{CoA}$ and presumably also with the reaction product mevalonate (Istvan 2001).

Pravastatin showed an estimated inhibition constant of $37.85 \mathrm{nM}$, which is in line with the fact that statins bind to the enzyme at nanomolar concentrations, whereas HMG-CoA binds at $4 \mu \mathrm{M}$ (Carbonell \& Freire 2005; Istvan 2001). Interestingly, EE was found to present an inhibition constant of the same order of units as pravastatin $(569.34 \mathrm{nM})$, while the rest of the dipeptides showed micromolar units. Similar binding constant units and/or modulating mechanisms have been previously described with peptides such as QDF derived from cowpea $\beta$-vignin protein, and the synthetic peptide GFPTGG, caprine milk-derived sequences NMAIHPR, TNAIPVYR and TNAIPYVRL, and soy $\beta$-conglycininderived peptides YVVNPDNDEN and YVVNPDNNEN (Fatchiyah \& Natasia 2018; Lammi et al. 2015; Lammi et al. 2016a, b; Pak et al. 2007; Silva et al. 2018; Zanoni et al. 2017).

According to these results, it was predicted that the studied dipeptides fit in the interface between the two subunits, quite similarly to the site occupied by pravastatin. As shown in Fig. 3, the dipeptides occupy the same binding site as the usual substrate HMG-CoA in the catalytic domain probably by the establishment of hydrogen bonds, hydrophobic interactions, and/or salt bridges. Docking studies have identified similar interacting residues with larger peptides (Fatchiyah \& Natasia, 
Table 4 HMG-CoAR binding site residues involved in docking interactions with pravastatin and dipeptides, with docking scores

\begin{tabular}{|c|c|c|c|c|c|c|}
\hline Pravastatin & $\begin{array}{l}\text { Binding energy } \\
\text { (kcal/mol) }\end{array}$ & $\begin{array}{l}\text { Inhibition } \\
\text { constant }\end{array}$ & $\begin{array}{l}\text { Protein residues involved in } \\
\text { H-bond interactions } \\
\text { (chain:residue) }\end{array}$ & $\begin{array}{l}\text { No. of } \mathrm{H} \\
\text { bonds }\end{array}$ & $\begin{array}{l}\text { Protein residues involved in } \\
\text { hydrophobic interactions } \\
\text { (chain:residue) }\end{array}$ & $\begin{array}{l}\text { Protein residues involved } \\
\text { in salt bridges (chain: } \\
\text { residue) }\end{array}$ \\
\hline$\overline{\mathrm{AA}}$ & -10.13 & $37,85(\mathrm{nM})$ & $\begin{array}{l}\text { C:Ser684 (Donor,sd) } \\
\text { C:Asp690 (Acceptor) } \\
\text { C:Asp690 (Acceptor) } \\
\text { C:Asp690 (Donor) } \\
\text { C:Lys691 (Donor,sd) } \\
\text { C:Lys692 (Donor,sd) } \\
\text { D:Glu559 (Acceptor,sd) } \\
\text { D:Asn755 (Donor,sd) }\end{array}$ & 8 & $\begin{array}{l}\text { C:Asn658 } \\
\text { C:Lys662 } \\
\text { D:His752 } \\
\text { D:Leu853 } \\
\text { D:Leu862 } \\
\text { D:Leu862 } \\
\text { D:Val863 } \\
\text { D:Val863 }\end{array}$ & $\begin{array}{l}\text { C:Arg590 (Carboxilate) } \\
\text { C:Lys692 (Carboxilate) } \\
\text { D:Lys735 (Carboxilate) }\end{array}$ \\
\hline$A L$ & -6.47 & $18.03(\mu \mathrm{M})$ & $\begin{array}{l}\text { C:Ser684 (Donor,sd) } \\
\text { C:Lys691 (Donor,sd) } \\
\text { D:Glu559 (Acceptor,sd) } \\
\text { D:Ala751 (Acceptor) } \\
\text { D:Asn755 (Donor,sd) }\end{array}$ & 5 & $\begin{array}{l}\text { D:His752 } \\
\text { D:Leu853 } \\
\text { D:Leu862 }\end{array}$ & $\begin{array}{l}\text { C:Arg590 (Carboxilate) } \\
\text { C:Lys692 (Carboxilate) } \\
\text { D:Lys735 (Carboxilate) }\end{array}$ \\
\hline $\mathrm{AQ}$ & -6.41 & $20.08(\mu \mathrm{M})$ & $\begin{array}{l}\text { C:Asp690 (Acceptor,sd) } \\
\text { D:Glu559 (Acceptor,sd) } \\
\text { D:Glu559 (Acceptor,sd) } \\
\text { D:His752 (Donor,sd) } \\
\text { D:Asn755 (Donor,sd) }\end{array}$ & 5 & $\begin{array}{l}\text { C:Asp690 } \\
\text { C:Lys691 } \\
\text { D:His752 }\end{array}$ & C:Arg590 (Carboxilate) \\
\hline DA & -6.58 & $15.08(\mu \mathrm{M})$ & $\begin{array}{l}\text { C:Asn658 (Acceptor,sd) } \\
\text { C:Asn658 (Acceptor,sd) } \\
\text { C:Ser661 (Donor,sd) } \\
\text { C:Lys662 (Donor,sd) } \\
\text { D:Gly560 (Acceptor) } \\
\text { D:Leu862 (Acceptor) }\end{array}$ & 6 & $\begin{array}{l}\text { D:Glu559 } \\
\text { D:Val863 }\end{array}$ & C:Arg590 (Carboxilate) \\
\hline $\mathrm{DD}$ & -6.92 & $8.51(\mu \mathrm{M})$ & $\begin{array}{l}\text { C:Ser684 (Donor,sd) } \\
\text { C:Asp690 (Acceptor,sd) } \\
\text { D:Glu559 (Acceptor,sd) } \\
\text { D:Glu559 (Acceptor,sd) } \\
\text { D:Ala751 (Acceptor) } \\
\text { D:Asn755 (Donor,sd) }\end{array}$ & 6 & $\begin{array}{l}\text { C:Lys691 } \\
\text { D:His752 }\end{array}$ & $\begin{array}{l}\text { C:Arg590 (Carboxilate) } \\
\text { C:Lys691 (Carboxilate) } \\
\text { C:Lys692 (Carboxilate) } \\
\text { D:Lys735 (Carboxilate) }\end{array}$ \\
\hline $\mathrm{EE}$ & -7.03 & $7.03(\mu \mathrm{M})$ & $\begin{array}{l}\text { C:Arg590 (Donor,sd) } \\
\text { C:Arg590 (Donor,sd) } \\
\text { C:Ser661 (Donor,sd) } \\
\text { C:Ser684 (Donor,sd) } \\
\text { C:Asp690 (Acceptor,sd) } \\
\text { C:Lys691 (Donor,sd) } \\
\text { D:Glu559 (Acceptor,sd) } \\
\text { D:Ala751 (Acceptor) }\end{array}$ & 8 & D:Leu853 & $\begin{array}{l}\text { C:Arg590 (Carboxilate) } \\
\text { C:Arg590 (Carboxilate) } \\
\text { C:Lys692 (Carboxilate) } \\
\text { C:Lys692 (Carboxilate) } \\
\text { D:Lys735 (Carboxilate) }\end{array}$ \\
\hline ES & -8.52 & $569.34(\mathrm{nM})$ & $\begin{array}{l}\text { C:Asn658 (Donor,sd) } \\
\text { C:Ser661 (Donor,sd) } \\
\text { C:Ser684 (Donor,sd) } \\
\text { D:Glu559 (Acceptor,sd) } \\
\text { D:Glu559 (Acceptor,sd } \\
\text { D:Asn755 (Donor,sd) }\end{array}$ & 6 & D:Leu853 & $\begin{array}{l}\text { C:Arg590 (Carboxilate) } \\
\text { C:Arg590 (Carboxilate) } \\
\text { C:Lys691 (Carboxilate) } \\
\text { C:Lys692 (Carboxilate) } \\
\text { D:Lys735 (Carboxilate) } \\
\text { D:Lys752 (Carboxilate) }\end{array}$ \\
\hline $\mathrm{LL}$ & -6.83 & $9.85(\mu \mathrm{M})$ & $\begin{array}{l}\text { C:Arg590 (Donor,sd) } \\
\text { C:Asn658 (Acceptor,sd) } \\
\text { C:Ser661 (Donor,sd) } \\
\text { C:Ser684 (Donor,sd) } \\
\text { C:Lys691 (Donor,sd) } \\
\text { C:Lys692 (Donor,sd) } \\
\text { D:Ala751 (Acceptor,sd) } \\
\text { D:Ala751 (Acceptor,sd) } \\
\text { D:Asn755 (Donor,sd) }\end{array}$ & 9 & D:Leu862 & $\begin{array}{l}\text { C:Arg590 (Carboxilate) } \\
\text { C:Arg590 (Carboxilate) } \\
\text { C:Lys692 (Carboxilate) } \\
\text { D:Lys735 (Carboxilate) }\end{array}$ \\
\hline QQ & -6.69 & $12.46(\mu \mathrm{M})$ & $\begin{array}{l}\text { C:Asp690 (Acceptor,sd) } \\
\text { D:Glu559 (Acceptor,sd) } \\
\text { D:Glu559 (Acceptor,sd) } \\
\text { D:His752 (Donor,sd) } \\
\text { D:Asn755 (Donor,sd) }\end{array}$ & 5 & $\begin{array}{l}\text { C:Lys691 } \\
\text { D:His752 }\end{array}$ & C:Arg590 (Carboxilate) \\
\hline $\mathrm{VH}$ & -5.91 & $46.66(\mu \mathrm{M})$ & C:Arg590 (Donor,sd) & 11 & D:Leu853 & C:Lys691 (Carboxilate) \\
\hline
\end{tabular}


Table 4 HMG-COAR binding site residues involved in docking interactions with pravastatin and dipeptides, with docking scores (Continued)

\begin{tabular}{|c|c|c|c|c|c|c|}
\hline Pravastatin & $\begin{array}{l}\text { Binding energy } \\
\text { (kcal/mol) }\end{array}$ & $\begin{array}{l}\text { Inhibition } \\
\text { constant }\end{array}$ & $\begin{array}{l}\text { Protein residues involved in } \\
\text { H-bond interactions } \\
\text { (chain:residue) }\end{array}$ & $\begin{array}{l}\text { No. of } \mathrm{H} \\
\text { bonds }\end{array}$ & $\begin{array}{l}\text { Protein residues involved in } \\
\text { hydrophobic interactions } \\
\text { (chain:residue) }\end{array}$ & $\begin{array}{l}\text { Protein residues involved } \\
\text { in salt bridges (chain: } \\
\text { residue) }\end{array}$ \\
\hline & & & $\begin{array}{l}\text { C:Asp690 (Acceptor,sd) } \\
\text { C:Lys692 (Donor,sd) } \\
\text { D:Gly560 (Acceptor) } \\
\text { D:Ser565 (Acceptor,sd) } \\
\text { D:Ser565 (Donor,sd) } \\
\text { D:Lys735 (Donor,sd) } \\
\text { D:His752 (Donor,sd) } \\
\text { D:Asn755 (Donor.sd) }\end{array}$ & & & \\
\hline Ligand & -6.53 & $16.3(\mu \mathrm{M})$ & $\begin{array}{l}\text { C:Arg590 (Donor,sd) } \\
\text { C:Asn658 (Acceptor,sd) } \\
\text { C:Asn658 (Acceptor,sd) } \\
\text { C:Asn658 (Donor,sd) } \\
\text { C:Ser661 (Donor,sd) } \\
\text { C:Lys691 (Donot,sd) } \\
\text { D:Glu559 (Acceptor,sd) } \\
\text { D:Gly560 (Acceptor) }\end{array}$ & 8 & & C:Arg590 (Carboxilate) \\
\hline
\end{tabular}

Key residues of the binding site are highlighted in bold. Common residues whereby pravastatin and dipeptides interact with are coloured in purple

2018), supporting the idea that these compounds can potentially act as statin analogues. The lower binding energies obtained in this last case may reflect the influence of the peptide size on the number of possible interactions with the enzyme, both by the increase of side chains and by the ability to adopt optimal conformations (Lin et al. 2015; Pak et al. 2010). Notwithstanding, conformations have been calculated considering a single ligand, but there is also the possibility to avoid the entry of the substrate if various dipeptides cooperate to block the binding sites of the enzyme, or that side chains of the residues interact among them forming complexes which block the binding site in a different way than predicted in this study.

\section{Conclusion}

Dipeptides AA, AL, AQ, DA, DD, EE, ES, LL, QQ, and $\mathrm{VH}$, generated in dry-cured ham have been reported for the first time to exert in vitro inhibitory activity of HMG-CoAR enzyme. Of all of them, DA, $\mathrm{DD}, \mathrm{EE}$ ES and LL presented greater inhibition percentages. Therefore, D- and E-residues might play a key role on the interaction between dipeptides and the enzyme. In the other hand, according to the molecular docking analysis, these peptides may act as structural analogues of HMG-CoA docking within the active site in a similar statin-interacting behaviour or they might prevent the substrate recognition by covering up the active site. Nonetheless, further studies are needed to confirm the bioavailability and efficacy of these peptides in vivo. These results support that dipetides generated during the proteolytic process of dry-cured ham, could act as in vitro modulators of HMG-CoA activity.

\section{Chemicals and reagents}

The dipeptides Ala-Ala (AA), Ala-Leu (AL), Ala-Gln (AQ), Ala-Trp (AW), Asp-Ala (DA), Asp-Asp (DD), Asp-Gly (DG), Glu-Glu (EE), Glu-Ser (ES), Glu-Val (EV), Gly-Ala (GA), Leu-Glu (LE), Leu-Leu (LL), ProAla (PA), Gln-Gln (QQ), Val-Gly (VG) and Val-His $(\mathrm{VH})$ were used in this study. The selected dipeptides of this work, listed in Table 1, were chosen for being present in dry-cured ham, but also for their attributed bioactivities as indicated in Table 2.

The following peptides AA (Catalog number: A9502), DA (Catalog number: A1277), and GA (Catalog number: G0502) were synthesised from Sigma-Aldrich (St. Louis, MO, USA); and dipeptides AL (Catalog number: 4005016), AQ (Catalog number:4003766), AW (Catalog number: 4006342), DD (Catalog number: 4010210), DG (Catalog number: 4001395), EE (Catalog number: 4000466), ES (Catalog number: 4005267), EV (Catalog number: 4001676), LE (Catalog number: 4016148), LL (Catalog number: 4001608), PA (Catalog number: 4011264), QQ (Catalog number: 4002313), VG (Catalog number: 4000404), and VH (Catalog number: 4002910) were purchased from Bachem AG (Bubendorf, Switzerland).

Peptide solutions were diluted in bidistilled water at different concentrations for HMG-CoAR inhibitory bioactivity assays. Set 1, composed by DA, DD, EE, ES, LL, and $\mathrm{VH}$ and Set 2, by $\mathrm{AA}, \mathrm{AL}, \mathrm{AQ}$, and QQ; were prepared by mixing peptide solutions to reach a final concentration of $1 \mathrm{mM}$. HMG-CoAR (catalytic domain), NADPH, assay buffer, and substrate solutions were provided in the HMG-CoA Reductase Assay Kit (Catalog number: CS1090; Sigma-Aldrich, St. Louis, MO, USA). Pravastatin sodium salt hydrate (Catalog number: P4498) was purchased from Sigma-Aldrich (St. Louis, MO, USA). 


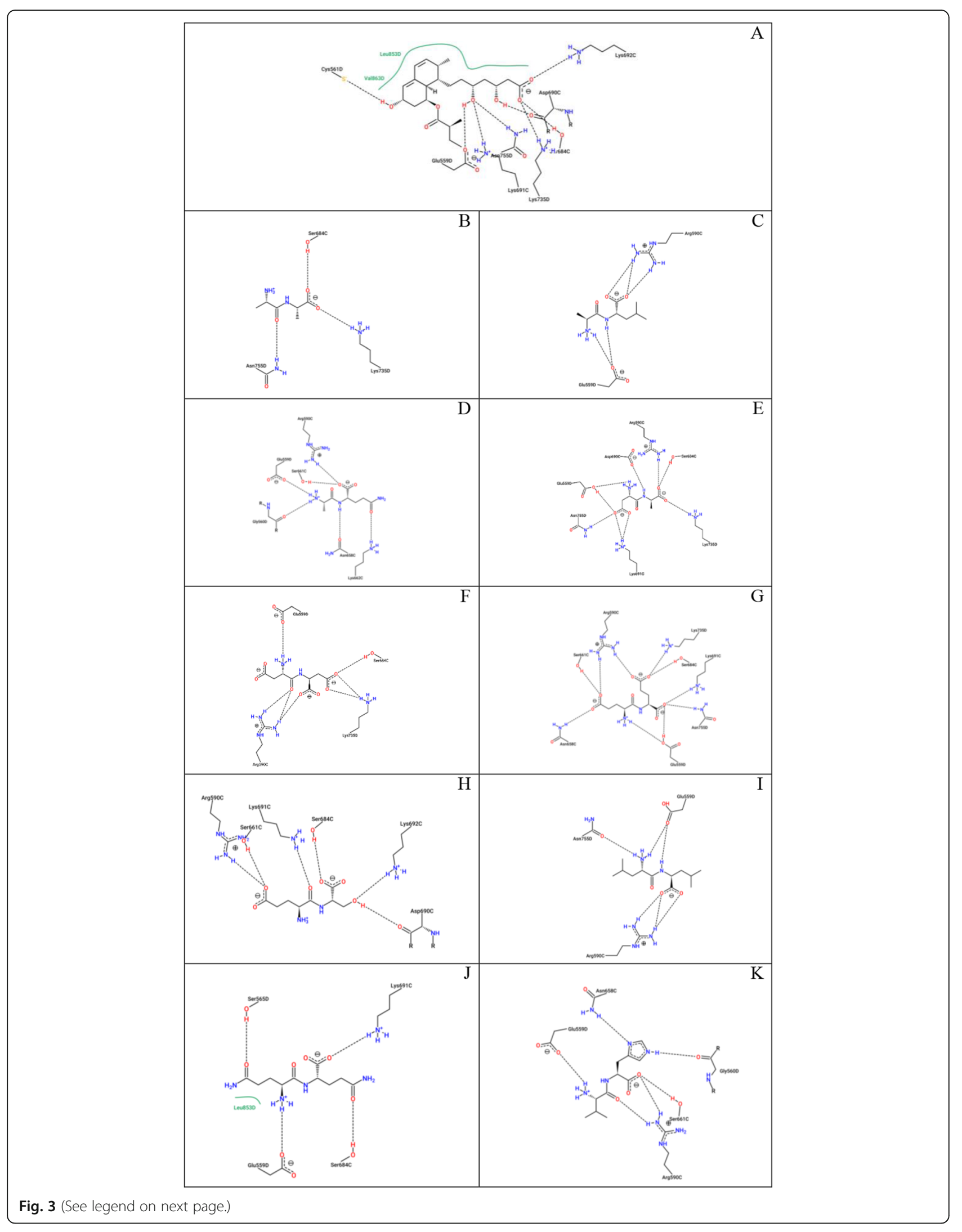


(See figure on previous page.)

Fig. 3 Two-dimensional representation of protein-ligand interactions between HMG-CoAR (ID 1DQ8) and A) Pravastatin (PubChem ID: 54687), AA (B, PubChem ID: 5484352), AL (C, PubChem ID: 96801), AQ (D, PubChem ID: 123935), DA (E, PubChem ID: 4677380), DD (F, PubChem ID: 332965), EE (G, PubChem ID: 439500), ES (H, PubChem ID: 6995653), LL (I, PubChem ID: 76807), QQ (J, PubChem ID: 7010588), and VH (K, PubChem ID: 7408625). $\mathrm{H}$ bonds are shown as dashed lines, hydrophobic contacts are represented by green splines and the corresponding pocket residues are also shown in the same colour. Diagrams obtained from ProteinPlus' PoseView tool (access Nov 2020)

\section{HMG-CoAR activity assay}

The assay is based on the spectrophotometric measurement of the decrease in absorbance at $340 \mathrm{~nm}$, which represents the oxidation of NADPH by the catalytic subunit of HMG-CoAR in the presence of the substrate HMG-CoA.

The protocol was carried out according to the manufacturer's instructions. Each reaction was prepared by adding the reagents in the following order: $1 \mathrm{X}$ assay buffer; dipeptide sample $(1 \mu \mathrm{L})$ or positive control pravastatin $(1 \mu \mathrm{l})$; NADPH $(4 \mu \mathrm{L})$; substrate solution $(12 \mu \mathrm{L})$; and finally, HMGCo-AR $(2 \mu \mathrm{L})$. Subsequently, the samples were mixed, and the absorbance at $340 \mathrm{~nm}$ was read at $37^{\circ} \mathrm{C}$ by a CLARIOstar microplate reader (BMG LAB$\mathrm{TECH}$, Ortenberg, Germany), from 0 to $10 \mathrm{~min}$. The HMG-CoA dependent oxidation of NADPH in the absence (Control) and presence of inhibitors, was measured by the absorbance decline, which is directly proportional to enzyme activity. Then, enzyme inhibition was calculated as follows:

$$
\% \text { Inhibition }=\left[\frac{\Delta \text { Abs } 100 \% \text { activity }-\Delta \text { Abs Sample }}{\Delta \text { Abs } 100 \% \text { activity }}\right] \times 100
$$

\section{Molecular docking}

Based on the inhibitory results, the dipeptides with higher inhibitory activity were selected for the in silico analysis in order to predict their potential interacting mechanism. Dipeptide sequences in "sdf" format were obtained from PubChem (Kim et al. 2019) and pdb files were extracted using Discovery Studio Visualizer v20.1.0. 19,295 (Dassault Systèmes BIOVIA Corp, 2020).

The structure of human HMG-CoAR (protein data bank ID: 1DQ8), in complex with HMG and CoA (Istvan et al. 2000), was downloaded from Protein Databank (PDB) (Berman, 2000).

The catalytic portion of the human HMG-CoAR is a tetramer which comprises the range of residues from position 459 to 863 (Jawaid et al. 2010). The monomers are arranged in two dimers, each of which has two active sites, and each active site is formed by residues from both monomers. Monomers of the catalytic portion consist of three domains: an $\mathrm{N}$-terminal "N-domain" (residues 460-527), a large and folded "L-domain" (residues 528-590 and 694-872) and a small "S-domain" (residues 592-682). The latter forms the binding site for $\operatorname{NADP}(\mathrm{H})$ and it is inserted into the L-domain (Istvan et al. 2000). The interface between both L- and S-domains originates the binding pocket for HMG (residues 684-692), which is the most important element in the binding of the substrate. If these residues interact with another molecule, it can no longer associate with HMGCoA (Fatchiyah \& Natasia, 2018). More specifically, the binding site is surrounded by key residues Arg590, Ser661, Val683, Ser684, Asp690, Lys691 from one subunit and Glu559, Cys561, Leu562, Ala564, Ser565, His752, Lys735, Asn755, Leu853, Ala856 from the another subunit (Shiuan et al. 2015). Residues Tyr479, Asp767, and His866, also contribute to the catalytic process (Lateef et al. 2020).

Ligand-protein docking simulations were carried out using AutoDock tools v1.5.6 and AutoDock v4.2.5.1 (The Scripps Research Institute) programs (Morris et al. 2009; Sanner, 1999).

Gasteiger charges and hydrogens were added to all molecules, water molecules were also removed from the enzyme, and ligand torsions were detected by AutoDock. Structure data files were converted into the Protein Data Bank partial charge and atom type format.

Grid Boxes $(60 \times 60 \times 60)$ were centred on one of the HMG, CoA and NADPH binding sites located at the interaction between chains $\mathrm{C}$ and $\mathrm{D}$, with coordinates $\mathrm{X}=17.146, \mathrm{Y}=16.96$, and $\mathrm{Z}=-36.37$, and spacing of $0.375 \AA$ (Istvan et al. 2000). Fifty docking runs were performed, using a Lamarckian genetic algorithm between flexible ligand and rigid receptor, a population size of 150, a maximum of 2,500,000 generations and $2,500,000$ evaluations for 50 GA runs. The root means square deviation tolerance was set to $2.0 \AA$ for the clustering of docking results. Analysis of the results was done by sorting the different complexes with respect to the predicted binding energy. The pose with lowest binding energy in each case was individually examined, and interactions were processed with online software Protein-Ligand Interaction Profiler (PLIP), to validate the interactions; and with ProteinsPlus, to obtain the two-dimensional representations by using PoseView algorithm (Fährrolfes et al. 2017; Salentin et al. 2015). 


\section{Statistical analysis}

Results are presented as means of 3 replicates \pm standard deviation. Statistical analysis was performed by one-way ANOVA and Fisher's multiple range tests for inhibition data using the software XLSTAT 2011 v5.01 (Addinsoft, Barcelona, Spain). Statistically significant differences were considered at $P<0.05$.

\begin{abstract}
Abbreviations
A: Ala, L-alanine; ACEl: Angiotensin I-converting enzyme;

CVDs: Cardiovascular diseases; D: Asp, L-aspartate; DPPs: Dipeptidyl peptidases; DPP-III: Dipeptidyl peptidase-III; DPP-IV: Dipeptidyl peptidase-IV; E, Glu: L-glutamate; F, Phe: L-phenylalanine; G, Gly: L-glycine; H, His: L-histidine; HDL: High-density-lipoproteins; HMG-CoA: 3-hydroxy-3-methylglutaryl-CoA; HMG-CoAR: 3-hydroxy-3-methylglutaryl-CoA reductase; I, lle: L-isoleucine; K, Lys: L-lysine; L, Leu: L-leucine; LDL: Low-density-lipoproteins; M, Met: Lmethionine; N, Asn: L-asparagine; NADPH: Nicotinamide adenine dinucleotide phosphate; P, Pro: L-proline; Q, Gln: L-glutamine; R, Arg: Larginine; $S$, Ser: L-serine; T, Thr: L-threonine; TG: Triglyceride; V, Val: L-valine; W, Trp: L-tryptophan; Y, Tyr: L-tyrosine
\end{abstract}

\section{Acknowledgements}

Not applicable.

\section{Authors' contributions}

$\mathrm{AH}$ developed the laboratory work and performed the experiments. $\mathrm{AH}$ and LM analyzed the data. AH drafted the manuscript. LM and FT revised the manuscript. All authors read and approved the final manuscript.

\section{Funding}

Grant AGL2017-89381-R from the Spanish Ministry of Economy, Industry and Competitivity and FEDER funds and Ramón y Cajal postdoctoral contract to LM are acknowledged.

\section{Availability of data and materials}

The datasets supporting the results of this article are included within the article and its additional files.

\section{Declarations}

Ethics approval and consent to participate

Not applicable.

\section{Consent for publication}

Not applicable.

\section{Competing interests}

Author Dr. Fidel Toldrá is a member of Editorial Board for Food Production, Processing and Nutrition, guest editor of Thematic Series of Bioactive Proteins and Peptides and he was not involved in the journal's review of, or decision related to this article.

Received: 3 November 2020 Accepted: 4 March 2021

Published online: 06 July 2021

\section{References}

Arai, S., Yamashita, M., \& Fujimaki, M. (1972). Glutamyl oligopeptides as factors responsible for tastes of a proteinase-modified soybean protein. Agricultural and Biological Chemistry, 36(7), 1253-1256.

Asao, M., Iwamura, H., Akamatsu, M., \& Fujita, T. (1987). Quantitative structureactivity relationships of the bitter thresholds of amino acids, peptides, and their derivatives. Journal of Medicinal Chemistry, 30(10), 1873-1879.

Bella, A. M., Erickson, R. H., \& Kim, Y. S. (1982). Rat intestinal brush border membrane dipeptidyl-aminopeptidase IV: Kinetic properties and substrate specificities of the purified enzyme. Archives of Biochemistry and Biophysics, 218(1), 156-162.

Berman, H. M. (2000). The protein data bank. Nucleic Acids Research, 28(1), 235242.
Bouglé, D., \& Bouhallab, S. (2017). Dietary bioactive peptides: Human studies. Critical Reviews in Food Science and Nutrition, 57(2), 335-343.

Carbonell, T., \& Freire, E. (2005). Binding thermodynamics of statins to HMG-CoA reductase t. Biochemistry, 44(35), 11741-11748.

Castellano, P., Mora, L., Escudero, E., Vignolo, G., Aznar, R., \& Toldrá, F. (2016). Antilisterial peptides from Spanish dry-cured hams : Puri fi cation and identi fi cation, (p. 59).

Cheung, H. S., Wang, F. L., Ondetti, M. A., Sabo, E. F., \& Cushman, D. W. (1980). Binding of peptide substrates and inhibitors of angiotensin converting enzyme. Importance of the $\mathrm{COOH}$-terminal dipeptide sequence. The Journal of Biological Chemistry, 255(2), 401-407. http://www.ncbi.nlm.nih.gov/ pubmed/6243277.

Coelho, M. S., Soares-Freitas, R. A. M., Arêas, J. A. G., Gandra, E. A., \& Salas-Mellado, M. de las M. (2018). Peptides from chia present antibacterial activity and inhibit cholesterol synthesis. Plant Foods for Human Nutrition, 73(2), 101-107.

Crisan, E., \& Patil, V. K. (2020). Neuromuscular Complications of Statin Therapy. Current Neurology and Neuroscience Reports, 20(10), 47. https://doi.org/10.1 007/s11910-020-01064-0.

Cushman, D. W., Cheung, H. S., Sabo, E. F., \& Ondetti, M. A. (1981). Evolution of a new class of antihypertensive drugs (page 19). In Z. P. Horovitz (Ed.), Angiotensin converting enzyme inhibitors: Mechanism of action and clinical implications (pp. 1-25). Urban \& Schwarzenberg, Baltimore-Munich.

Dassault Systèmes BIOVIA (2020). Discovery Studio Visualizer; v20.1.0.19295; Dassault Systèmes: San Diego, CA, USA.

Dhanda, S., Singh, H., Singh, J., \& Singh, T. P. (2007). Isolation, purification and characterization of a DPP-III homologue from goat brain. Protein Expression and Purification, 52(2), 297-305.

Escudero, E., Aristoy, M. C., Nishimura, H., Arihara, K., \& Toldrá, F. (2012). Antihypertensive effect and antioxidant activity of peptide fractions extracted from Spanish dry-cured ham. MESC, 91(3), 306-311.

Escudero, E., Mora, L., Fraser, P. D., Aristoy, M. C., Arihara, K., \& Toldrá, F. (2013). Purification and identification of antihypertensive peptides in Spanish drycured ham. Journal of Proteomics, 78, 499-507. https://doi.org/10.1016/j. jprot.2012.10.019.

Fährrolfes, R., Bietz, S., Flachsenberg, F., Meyder, A., Nittinger, E., Otto, T., ... Rarey, M. (2017). ProteinsPlus: A web portal for structure analysis of macromolecules. Nucleic Acids Research, 45(W1), W337-W343.

Fatchiyah, F., \& Natasia, S. C. (2018). Inhibition potency of HMGR enzyme against hypercholesterolemia by bioactive peptides of CSN1S2 protein from caprine milk. 070014.

Fürst, P., Alteheld, B., \& Stehle, P. (2004). Why should a single nutrient Glutamine - Improve outcome ? The remarkable story of glutamine dipeptides. Clinical Nutrition Supplements, 1, 3-15.

Gallego, M., Aristoy, M. C., \& Toldrá, F. (2014). Dipeptidyl peptidase IV inhibitory peptides generated in Spanish dry-cured ham. MESC, 96(2), 757-761.

Gallego, M., Grootaert, C., Mora, L., Aristoy, M. C., Van Camp, J., \& Toldrá, F. (2016). Transepithelial transport of dry-cured ham peptides with ACE inhibitory activity through a Caco-2 cell monolayer. Journal of Functional Foods, 21, 388-395. https://doi.org/10.1016/j.jff.2015.11.046.

Gallego, M., Mora, L., Aristoy, M. C., \& Toldrá, F. (2015). Titin-derived peptides as processing time markers in dry-cured ham. Food Chemistry, 167, 326-339. https://doi.org/10.1016/j.foodchem.2014.06.088.

Gallego, M., Mora, L., \& Toldrá, F. (2019a). Potential cardioprotective peptides generated in Spanish dry-cured ham. Journal of Food Bioactives, 6, 110-117. https://doi.org/10.31665/jfb.2019.6188.

Gallego, M., Mora, L., \& Toldrá, F. (2019b). The relevance of dipeptides and tripeptides in the bioactivity and taste of dry-cured ham. Food Production, Processing and Nutrition, 1(1), 1-14. https://doi.org/10.1186/s43014-019-0002-7.

Gesto, D. S., Pereira, C. M. S., Cerqueira, N. M. F. S., \& Sousa, S. F. (2020). An atomic-level perspective of HMG-CoA-Reductase: The target enzyme to treat hypercholesterolemia. Molecules, 25(17), 3891.

Guha, S., \& Majumder, K. (2019). Structural-features of food-derived bioactive peptides with anti-inflammatory activity: A brief review. Journal of Food Biochemistry, 43(1), e12531.

Gupta, S., Sharma, A. K., Shastri, V., Madhu, M. K., \& Sharma, V. K. (2017). Prediction of anti-inflammatory proteins/peptides: An insilico approach. Journal of Translational Medicine, 15(1), 1-11.

Hashiguchi, M., Hakamata, J., Shimizu, M., Maruyama, J., Shiga, T., \& Mochizuki, M. (2018). Risk factors for rhabdomyolysis with HMG-CoA reductase inhibitors identified using a postmarketing surveillance database in Japan. International Journal of Clinical Pharmacology and Therapeutics, 56(07), 310-320. 
Hikida, A., Ito, K., Motoyama, T., Kato, R., \& Kawarasaki, Y. (2013). Systematic analysis of a dipeptide library for inhibitor development using human dipeptidyl peptidase IV produced by a Saccharomyces cerevisiae expression system. Biochemical and Biophysical Research Communications, 430(4), $1217-$ 1222. https://doi.org/10.1016/j.bbrc.2012.12.073.

Istvan, E. S. (2001). Structural mechanism for statin inhibition of HMG-CoA reductase. Science, 292(5519), 1160-1164.

Istvan, E. S., Palnitkar, M., Buchanan, S. K., \& Deisenhofer, J. (2000). Crystal structure of the catalytic portion of human HMG-CoA reductase: Insights into regulation of activity and catalysis. The EMBO Journal, 19(5), 819-830.

Jawaid, S., Gertz, M., Corsino, C., Cheung, J., Seidle, H., \& Couch, R. D. (2010). Human hydroxymethylglutaryl-coenzyme A reductase (HMGCR) and statin sensitivity. Indian Journal of Biochemistry \& Biophysics, 47(6), 331-339.

Kęska, P., \& Stadnik, J. (2016). Porcine myofibrillar proteins as potential precursors of bioactive peptides - An in silico study. Food \& Function, 7, 2878-2885.

Kęska, P., \& Stadnik, J. (2017). Taste-active peptides and amino acids of pork meat as components of dry-cured meat products: An in-silico study. Journal of Sensory Studies, 32(6), e12301.

Kim, M. J., Son, H. J., Kim, Y., Misaka, T., \& Rhyu, M.-R. (2015). Umami-bitter interactions: The suppression of bitterness by umami peptides via human bitter taste receptor. Biochemical and Biophysical Research Communications, 456(2), 586-590.

Kim, S., Chen, J., Cheng, T., Gindulyte, A., He, J., He, S., ... Bolton, E. E. (2019). PubChem 2019 update: Improved access to chemical data. Nucleic Acids Research, 47(D1), D1102-D1109.

Kuramitsu, R., Takahashi, M., Tahara, K., Nakamura, K., \& Okai, H. (1996). Tastes produced by peptides containing ionic groups and by related compounds. Bioscience, Biotechnology, and Biochemistry, 60(10), 1637-1642.

La Manna, S., Di Natale, C., Florio, D., \& Marasco, D. (2018). Peptides as therapeutic agents for inflammatory-related diseases. International Journal of Molecular Sciences, 19(9), 1-18.

Lammi, C., Aiello, G., Vistoli, G., Zanoni, C., Arnoldi, A., Sambuy, Y., ... Ranaldi, G. (2016a). A multidisciplinary investigation on the bioavailability and activity of peptides from lupin protein. Journal of Functional Foods, 24, 297-306.

Lammi, C., Zanoni, C., Aiello, G., Arnoldi, A., \& Grazioso, G. (2016b). Lupin peptides modulate the protein-protein interaction of PCSK9 with the low density lipoprotein receptor in HepG2 cells. Scientific Reports, 6(1), 29931.

Lammi, C., Zanoni, C., Arnoldi, A., \& Vistoli, G. (2015). Two peptides from soy $\beta$ Conglycinin induce a hypocholesterolemic effect in HepG2 cells by a statinlike mechanism: Comparative in vitro and in silico modeling studies. Journal of Agricultural and Food Chemistry, 63(36), 7945-7951.

Lammi, C., Zanoni, C., Scigliuolo, G. M., D'Amato, A., \& Arnoldi, A. (2014). Lupin peptides lower low-density lipoprotein (LDL) cholesterol through an upregulation of the $L D L$ receptor/sterol regulatory element binding protein 2 (SREBP2) pathway at HepG2 cell line. Journal of Agricultural and Food Chemistry, 62(29), 7151-7159.

Lan, V. T. T., Ito, K., Ohno, M., Motoyama, T., Ito, S., \& Kawarasaki, Y. (2015). Analyzing a dipeptide library to identify human dipeptidyl peptidase IV inhibitor. Food Chemistry, 175, 66-73.

Lateef, T., Naeem, S., \& Qureshi, S. A. (2020). In-silico studies of HMG-Co A reductase inhibitors present in fruits of Withania coagulans Dunal (Solanaceae). Tropical Journal of Pharmaceutical Research, 19(2), 305-312.

Lin, S.-H., Chang, D.-K., Chou, M.-J., Huang, K.-J., \& Shiuan, D. (2015). Peptide inhibitors of human HMG-CoA reductase as potential hypocholesterolemia agents. Biochemical and Biophysical Research Communications, 456(1), 104109.

Liu, R., Zheng, W., Li, J., Wang, L., Wu, H., Wang, X., \& Shi, L. (2015). Rapid identification of bioactive peptides with antioxidant activity from the enzymatic hydrolysate of Mactra veneriformis by UHPLC-Q-TOF mass spectrometry. Food Chemistry, 167, 484-489. https://doi.org/10.1016/j. foodchem.2014.06.113.

Loponen, J. (2008). Angiotensin converting enzyme inhibitory peptides in Finnish cereals: a database survey. Agricultural and Food Science, 13(1-2), 39. https:// doi.org/10.2137/1239099041837932.

Maehashi, K., Matsuzaki, M., Yamamoto, Y., \& Udaka, S. (1999). Isolation of peptides from an enzymatic hydrolysate of food proteins and characterization of their taste properties. Bioscience, Biotechnology, and Biochemistry, 63(3), 555-559.

Marques, M. R., Soares Freitas, R. A. M., Corrêa Carlos, A. C., Siquemoto, É. S., Fontanari, G. G., \& Arêas, J. A. G. (2015). Peptides from cowpea present antioxidant activity, inhibit cholesterol synthesis and its solubilisation into micelles. Food Chemistry, 168, 288-293.

Martínez-Sánchez, S. M., Minguela, A., Prieto-Merino, D., Zafrilla-Rentero, M. P., Abellán-Alemán, J., \& Montoro-García, S. (2017). The effect of regular intake of dry-cured ham rich in bioactive peptides on inflammation, platelet and monocyte activation markers in humans. Nutrients, 9(4), 1-11.

Meisel, H., Walsh, D. J., Murray, B., \& FitzGerald, R. J. (2006). ACE inhibitory peptides. In Y. Mine \& F. Shahidi (Eds.), Nutraceutical proteins and peptides in health and disease (pp. 269-315). CRC Taylor \& Francis Group, Boca Raton, London, New York.

Montoro-García, S., Zafrilla-Rentero, M. P., Celdrán-de Haro, F. M., Piñero-de Armas, J. J., Toldrá, F., Tejada-Portero, L., \& Abellán-Alemán, J. (2017). Effects of drycured ham rich in bioactive peptides on cardiovascular health: A randomized controlled trial. Journal of Functional Foods, 38, 160-167.

Mora, L., Calvo, L., Escudero, E., \& Toldrá, F. (2016). Differences in pig genotypes influence the generation of peptides in dry-cured ham processing. Food Research International, 86, 74-82. https://doi.org/10.1016/j.foodres.2016.04. 023.

Mora, L., Gallego, M., \& Toldrá, F. (2019). Degradation of myosin heavy chain and its potential as a source of natural bioactive peptides in drycured ham. Food Bioscience, 30(September 2018), 100416. https://doi.org/10.1016/j.fbio.2019.1 00416

Mora, L., González-Rogel, D., Heres, A., \& Toldrá, F. (2020). Iberian dry-cured ham as a potential source of a -glucosidase-inhibitory peptides. Journal of Functional Foods, 67(February), 103840.

Morifuji, M., Koga, J., Kawanaka, K., \& Higuchi, M. (2009). Branched-chain amino acid-containing dipeptides, identified from whey protein hydrolysates, stimulate glucose uptake rate in $L 6$ myotubes and isolated skeletal muscles. Journal of Nutritional Science and Vitaminology, 55(1), 81-86.

Morris, G. M., Huey, R., Lindstrom, W., Sanner, M. F., Belew, R. K., Goodsell, D. S., \& Olson, A. J. (2009). AutoDock4 and AutoDockTools4: Automated docking with selective receptor flexibility. Journal of Computational Chemistry, 30(16), 2785-2791.

Nagaoka, S. (2019). Structure-function properties of hypolipidemic peptides. Journal of Food Biochemistry, 43(1), e12539.

Noguchi, M., Arai, S., Yamashita, M., Kato, H., \& Fujimaki, M. (1975). Isolation and identification of acidic oligopeptides occurring in a flavor potentiating fraction from a fish protein hydrolysate. Journal of Agricultural and Food Chemistry, 23(1), 49-53.

Nongonierma, A. B., Mooney, C., Shields, D. C., \& FitzGerald, R. J. (2014). In silico approaches to predict the potential of milk protein-derived peptides as dipeptidyl peptidase IV (DPP-IV) inhibitors. Peptides, 57, 43-51. https://doi. org/10.1016/j.peptides.2014.04.018.

Ochs-Balcom, H. M., Nguyen, L. M., Ma, C., Isackson, P. J., Luzum, J. A., Kitzmiller, J. P.,... Vladutiu, G. D. (2019). Clinical features related to statin-associated muscle symptoms. Muscle and Nerve, 59(5), 537-543.

Ohyama, S., Ishibashi, N., Tamura, M., Nishizaki, H., \& Okai, H. (1988). Synthesis of bitter peptides composed of aspartic acid and glutamic acid. Agricultural and Biological Chemistry, 52(3), 871-872.

Pak, V. V., Kim, S. H., Koo, M., Lee, N., Shakhidoyatov, K. M., \& Kwon, D. Y. (2006). Peptide design of a competitive inhibitor for HMG-CoA reductase based on statin structure. Biopolymers, 84(6), 586-594.

Pak, V. V., Koo, M., Kim, M. J., Yang, H. J., Yun, L., \& Kwon, D. Y. (2008). Modeling an active conformation for linear peptides and design of a competitive inhibitor for HMG-CoA reductase. Journal of Molecular Recognition, 21(4), 224-232.

Pak, V. V., Koo, M., Kwon, D. Y., Shakhidoyatov, K. M., \& Yun, L. (2010). Peptide fragmentation as an approach in modeling of an active peptide and designing a competitive inhibitory peptide for $\mathrm{HMG}-\mathrm{CoA}$ reductase. Bioorganic \& Medicinal Chemistry, 18(12), 4300-4309.

Pak, V. V., Koo, M., Kwon, D. Y., \& Yun, L. (2012). Design of a highly potent inhibitory peptide acting as a competitive inhibitor of $\mathrm{HMG}-\mathrm{COA}$ reductase. Amino Acids, 43(5), 2015-2025

Pak, V. V., Koo, M., Lee, N., Kim, M. S., \& Kwon, D. Y. (2005a). Structure-Activity relationships of the peptide Ile-Ala-Val-Pro and its derivatives revealed using the semi-empirical AM1 method. Chemistry of Natural Compounds, 41(4), 454-460.

Pak, V. V, Koo, M. S., Kasymova, T. D., \& Kwon, D. Y. (2005b). Isolation and Identification of Peptides from Soy 11S-Globulin with Hypocholesterolemic Activity. Chemistry of Natural Compounds, 41(6), 710-714. https://doi.org/10.1 007/s10600-006-0017-6. 
Pak, V. V., Koo, M., Yun, L., \& Kwon, D. Y. (2007). Recognized sequence and conformation in design of linear peptides as a competitive inhibitor for HMG-CoA reductase. Journal of Molecular Recognition, 20(3), 197-203.

Pak, V. V, Koo, M., Lee, N., Oh, S. K., Kim, M. S., Lee, J.-S., \& Kwon, D. Y. (2005c). Hypocholesterolemic Soybean Peptide (IAVP) Inhibits HMG-CoA Reductase in a Competitive Manner. In Food Science and biotechnology (Vol. 14, Issue 6, pp. 727-731)

Rebollo, A. J. G., Botejara, E. M., Cansado, A. O., Morales, P. J., Bellido, M. M., Sánchez, A. F., ... Alvarez, J. E. C. (1998). Effects of consumption of meat product rich in monounsaturated fatty acids (the ham from the Iberian pig) on plasma lipids. Nutrition Research, 18(4), 743-750.

Ringseis, R., Matthes, B., Lehmann, V., Becker, K., Schöps, R., Ulbrich-Hofmann, R., \& Eder, K. (2005). Peptides and hydrolysates from casein and soy protein modulate the release of vasoactive substances from human aortic endothelial cells. Biochimica et Biophysica Acta (BBA) - General Subjects, 1721(1-3), 89-97.

Rinto, D. R., Yasni, S., \& Suhartono, M. (2017). Novel HMG-CoA Reductase Inhibitor Peptide from Lactobacillus acidophilus isolated from Indonesian fermented food.

Ruiz-Canela López, M., Bes-Rastrollo, M., Zazpe, I., Martínez, J. A., Cuervo, M., \& Martínez-González, M. Á. (2009). Consumo de jamón curado e incidencia de episodios cardiovasculares, hipertensión arterial o ganancia de peso. Medicina Clínica, 133(15), 574-580.

Salentin, S., Schreiber, S., Haupt, V. J., Adasme, M. F., \& Schroeder, M. (2015). PLIP: Fully automated protein-ligand interaction profiler. Nucleic Acids Research, 43(W1), W443-W447.

Sanner, M. F. (1999). Python: A programming language for software integration and development. Journal of Molecular Graphics \& Modelling, 17(1), 57-61.

Sentandreu, M. A., \& Toldrá, F. (2007). Evaluation of ACE inhibitory activity of dipeptides generated by the action of porcine muscle dipeptidyl peptidases. Food Chemistry, 102(2), 511-515

Shim, J., Son, H. J., Kim, Y., Kim, K. H., Kim, J. T., Moon, H., ... Rhyu, M.-R. (2015). Modulation of sweet taste by umami compounds via sweet taste receptor subunit hT1R2. PLoS One, 10(4), e0124030.

Silva, M. B. d. C. e., Souza, C. A. d. C., Philadelpho, B. O., Cunha, M. M. N. d., Batista, F. P. R., Silva, J. R. d., ... Ferreira, E. S. (2018). In vitro and in silico studies of 3hydroxy-3-methyl-glutaryl coenzyme A reductase inhibitory activity of the cowpea Gln-Asp-Phe peptide. Food Chemistry, 259, 270-277.

Soares, R., Mendonça, S., de Castro, L. I.., Menezes, A., \& Arêas, J. (2015). Major peptides from amaranth (Amaranthus cruentus) protein inhibit HMG-COA reductase activity. International Journal of Molecular Sciences, 16(2), 4150-4160.

Suganya, S., Nandagopal, B., \& Anbarasu, A. (2017). Natural inhibitors of HMG-CoA reductase-an insilico approach through molecular docking and simulation studies. Journal of Cellular Biochemistry, 118(1), 52-57.

Tamura, M., Nakatsuka, T., Tada, M., Kawasaki, Y., Kikuchi, E., \& Okai, H. (1989). The relationship between taste and primary structure of "delicious peptide" (LysGly-Asp-Glu-Glu-Ser-Leu-Ala) from beef soup. Agricultural and Biological Chemistry, 53(2), 319-325.

Toldrá, F., Gallego, M., Reig, M., Aristoy, M.-C., \& Mora, L. (2020). Recent Progress in Enzymatic Release of Peptides in Foods of Animal Origin and Assessment of Bioactivity. Journal of Agricultural and Food Chemistry, 68(46), 12842-12855. https://doi.org/10.1021/acs.jafc.9b08297.

Udenigwe, C. C., Li, H., \& Aluko, R. E. (2012). Quantitative structure - activity relationship modeling of renin-inhibiting dipeptides. 1379-1386. https://doi. org/10.1007/s00726-011-0833-2.

van den Oord, A. H. A. \& van Wassenaar, P. D. (1997). Umami peptides: Assessment of their alleged taste properties. Zeitschrift Für Lebensmitteluntersuchung Und -Forschung A, 205(2), 125-130.

van Platerink, C. J., Janssen, H.-G. M., \& Haverkamp, J. (2008). Application of at-line two-dimensional liquid chromatography-mass spectrometry for identification of small hydrophilic angiotensin I-inhibiting peptides in milk hydrolysates. Analytical and Bioanalytical Chemistry, 391(1), 299-307. https:// doi.org/10.1007/s00216-008-1990-3.

Virginia, A., Rachmawati, H., Riani, C., \& Retnoningrum, D. S. (2016). Study of HMG CoA reductase inhibition activity of the hydrolyzed product of snakehead fish (Channa striata) skin collagen with $50 \mathrm{kDa}$ collagenase from Bacillus licheniformis F11.4. Scientia Pharmaceutica, 84(1), 81-88.

Yao, S., Agyei, D., \& Udenigwe, C. C. (2018). Structural basis of bioactivity of food peptides in promoting metabolic health, (pp. 145-181).

Zalesin, K. C., Franklin, B. A., Miller, W. M., Peterson, E. D., \& McCullough, P. A. (2011). Impact of obesity on cardiovascular disease. Medical Clinics of North America, 95(5), 919-937.
Zanoni, C., Aiello, G., Arnoldi, A., \& Lammi, C. (2017). Investigations on the hypocholesterolaemic activity of LILPKHSDAD and LTFPGSAED, two peptides from lupin $\beta$-conglutin: Focus on LDLR and PCSK9 pathways. Journal of Functional Foods, 32, 1-8.

Zhao, L., Wang, X., Zhang, X. L., \& Xie, Q. F. (2016). Purification and identification of anti-inflammatory peptides derived from simulated gastrointestinal digests of velvet antler protein (Cervus elaphus Linnaeus). Journal of Food and Drug Analysis, 24(2), 376-384.

Zhou, C. Y., Tang, C.-B., Wang, C., Dai, C., Bai, Y., Yu, X.-B., Li, C.-B., Xu, X.-L., Zhou, G.-H., \& Cao, J.-X. (2020). Insights into the evolution of myosin light chain isoforms and its effect on sensory defects of dry-cured ham. Food Chemistry, 315, 126318. https://doi.org/10.1016/j.foodchem.2020.126318.

Zhou, Y. P., Jiang, Z. M., Sun, Y. H., He, G. Z., \& Shu, H. (2004). The effects of supplemental glutamine dipeptide on gut integrity and clinical outcome after major escharectomy in severe burns: A randomized, double-blind, controlled clinical trial. Clinical Nutrition, Supplement, 1(1), 55-60.

\section{Publisher's Note}

Springer Nature remains neutral with regard to jurisdictional claims in published maps and institutional affiliations.
Ready to submit your research? Choose BMC and benefit from:

- fast, convenient online submission

- thorough peer review by experienced researchers in your field

- rapid publication on acceptance

- support for research data, including large and complex data types

- gold Open Access which fosters wider collaboration and increased citations

- maximum visibility for your research: over $100 \mathrm{M}$ website views per year

At $\mathrm{BMC}$, research is always in progress.

Learn more biomedcentral.com/submissions 